\title{
10. Nearly All About Kevin: The election as drawn by Australian cartoonists
}

\author{
Haydon Manning and Robert Phiddian
}

In her account of the Danish cartoon furore of 2005, Klausen (2009: 6) notes that 'political cartoons tell a story or make a comment on current events', and 'use exaggerated physiognomic features to make a statement about the fundamental nature of a person or thing'. On the subject of 'person', it is our contention that the cartoons of the 2013 election broadly mirrored the wider campaign, particularly in focusing on the nature and antics of Prime Minister Rudd and less on those of his challenger, Tony Abbott.

To all dispassionate spectators, 2013 was an election where a change of government was all but guaranteed, but the newly reminted PM clearly believed that a miracle resurrection of Labor's fortunes was possible. As Peter Hartcher (2013), a regular media confidant of Rudd, wrote after the election: 'He did not insist that he would challenge only if election victory were guaranteed; he told his most senior supporters that he was prepared to run if Labor had a 30 per cent chance of winning the election'. Whether or not this was a realistic possibility, the cartoonists (in their role as instant graphic historians in the wide range of capital city and regional newspapers surveyed for this chapter) duly told the story that Rudd tried and failed to make the running while Abbott mostly succeeded in playing the disciplined small target. So in relation to the lower house contest the cartoonists generally told an accurate if unsurprising story centred on personalities.

However, the Senate contest was far more open and unpredictable than that of the House of Representatives. A plethora of minor and micro parties, all keen to 'harvest' preferences, saw Senate ballot papers expanding to the size of a small tablecloth. Most voters were quite happy to sign away control of the flows of preferences by voting 'above the line', even though the consequences will be with us for six years.

Hence, a more perceptive comment on the election is David Pope's prescient cartoon on the eventual make-up of the Senate that anticipated the most remarkable 'thing' to emerge from the election. It also represents one of the earliest calls for reform of how the Senate vote is orchestrated and counted (see Green's chapter). The child's comment to his bemused father about remembering 'the inflatable Fielding' is particularly poignant as it reminds us that in the 2004 
Senate election in Victoria, Family First Party candidate Stephen Fielding, with the benefit of ALP preference support, was elected on a primary vote of merely 1.8 per cent. However, compared to Ricky Muir's 2013 success in Victoria from 0.51 per cent on the initial count, Fielding's vote begins to look like a solid sort of mandate!

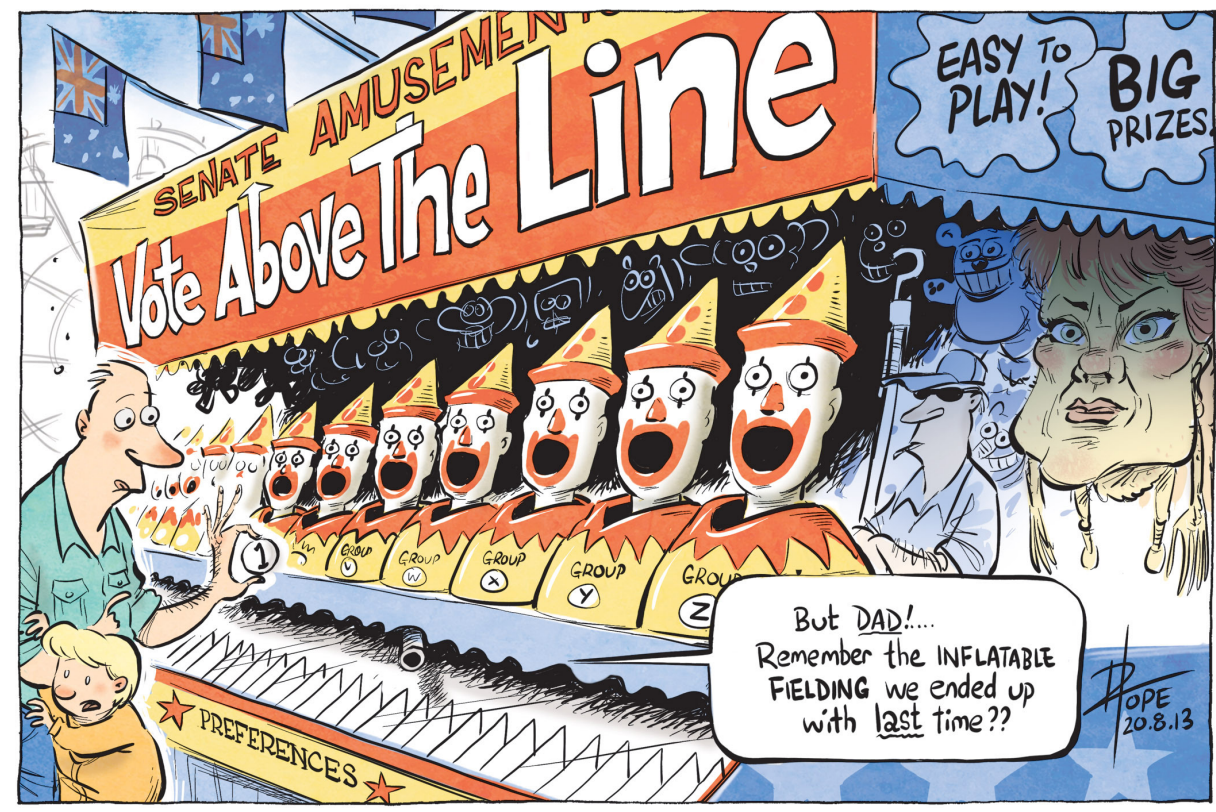

Figure 1

Source: David Pope, The Canberra Times, 20 August 2013.

Cartoons considered for this study appeared in the online websites of the major capital city daily newspapers and also The Australian and the Australian Financial Review. The focus was on editorial page cartoons and front page 'pocket cartoons'. Over the six weeks of the campaign 383 cartoons were filed for showing to an audience of colleagues and students. Assessing audience response and subsequent conversation regarding the insight and comic impact of the collection informed our selection, but equally the task of chronicling the key machinations of campaign 2013 influenced our selection.

\section{The 'licence to mock'}

Colin Seymour-Ure (2001) explains that the cartoonists' use of caricature and pithy comment is essentially about making two types of observations regarding those who govern - or seek to govern - us. The first is an essential definition or 
interpretation, as in: 'this is what the prime minister is really like'. The second and stronger type in terms of the cartoonists' armoury is a bolt of criticism, such as: 'he is a fool'. The two-part process is neatly illustrated by Jon Kudelka's take on Rudd's growing obsession with 'selfie' photos:

\section{SELFIE SELFIE} IN MY HAND, WHO'S THE FAIREST IN THE LAND...?

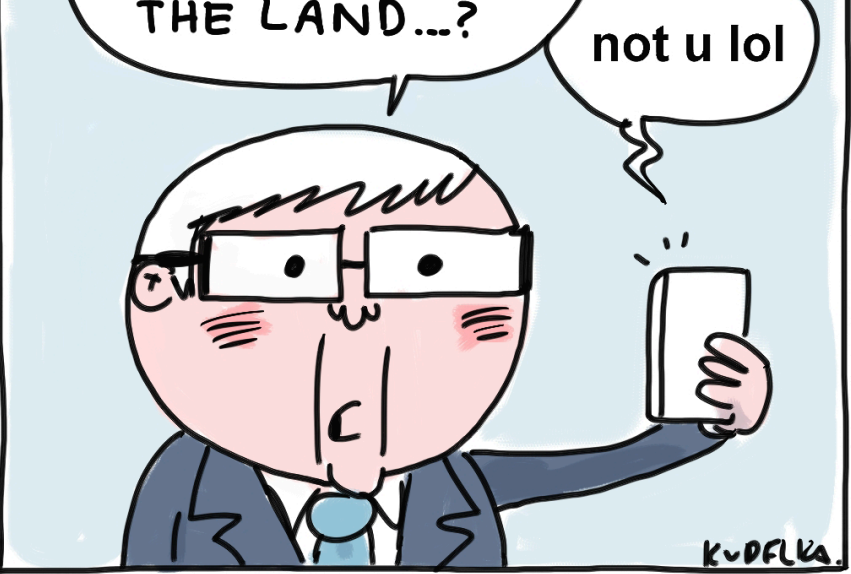

Figure 2

Source: Jon Kudelka, The Australian, 31 August 2013.

The 'selfie' on the nightly news became almost as closely associated with Rudd as the cigar was with Churchill, so many commentators and voters came to conclude he had a strong streak of narcissism. The 'mirror, mirror on the wall' reference to the vain queen in Snow White precisely reflects this view, absurdly confirmed by an earlier act of unusual publicity from the PM. In early July, Rudd posted an Instagram photo of himself having cut his face while shavingthis quickly 'went viral'. While many thought this pursuit of celebrity culture unbecoming in a national leader and others point to it engaging with younger voters (Leys 2013), there is no question that it was a gift to cartoonists and other satirists.

The cartoon is thus 'an editorial in pictures' (Seymour-Ure 2001: 335), meaning the better cartoonists earn 'a wary kind of respect' (Seymour-Ure 2003: 230). They employ the satirist's arsenal of ridicule, parody, metaphor and archetype, as outlined by scholars such as Gombrich (1978), Press (1981), Seymour-Ure (1997; 2001; 2003), Condren (2012) and Phiddian (2013). As Elizabeth El Refaie (2008: 184-5) explains, the: 
political cartoon constitutes a very specific genre, with its own history, distinctive styles, conventions and communicative purposes [and while] not always humorous, they do generally contain an element of irony or at least something incongruous or surprising.

Consequently, Australian art critic and curator Joan Kerr points out that political cartoons derive not from the 'maleness, whiteness or gloominess' of the cartoonist but rather from their capacity to 'show us as we are, warts and all - indeed, warts above all - in ways that we all understand and appreciate' (Kerr 1999: 78). Importantly, they are assured a daily audience - which now includes the ease of online access and forwarding on to friends - numbering in the hundreds of thousands. Though newspapers may have a troubled business model in the world of new media, cartoons and their descendants in visual satire are enjoying a healthy period of development.

It is clear from surveying the cartoonists' view at each election since 1996, that they take the 'citizens' perspective' on the policy sales campaign and leaders' efforts to scare voters into jumping at policy shadows. A common theme found in election cartoons is impatience at the debasement of national political life by the political classes at a time that should be a celebration of democracy. The following cartoons by Cathy Wilcox, John Spooner and Pat Campbell express the cartoonists' and the voters' varying levels of anger and contempt.

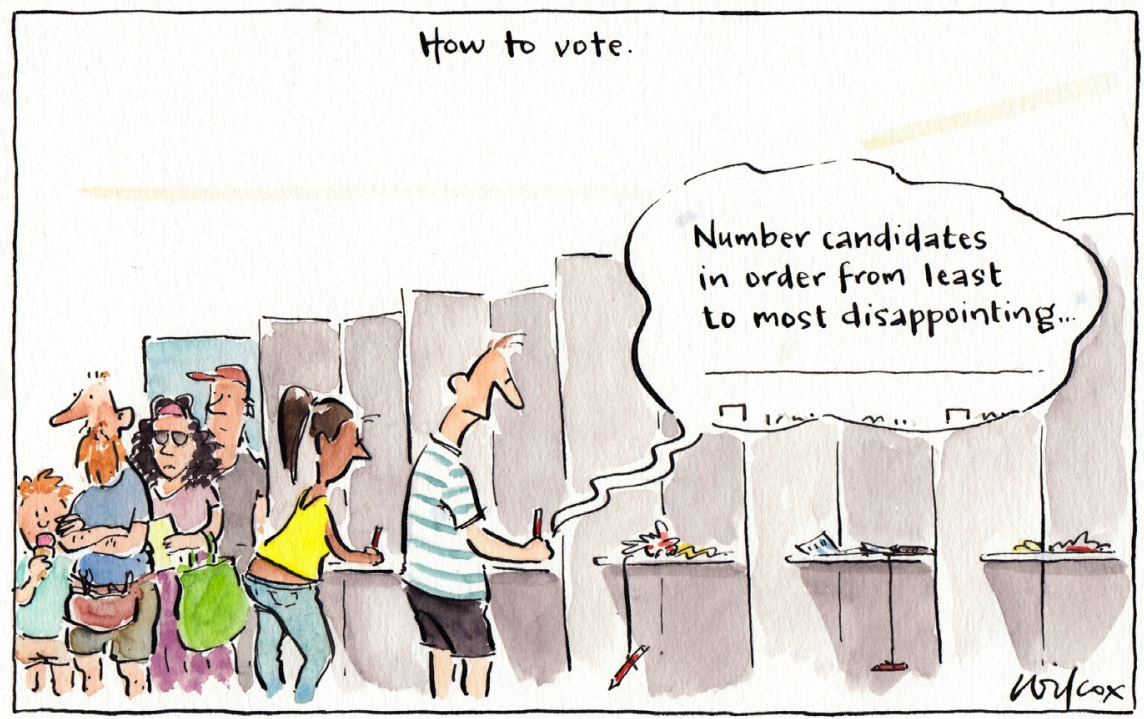

Figure 3

Source: Cathy Wilcox, The Sydney Morning Herald, l September 2013. 


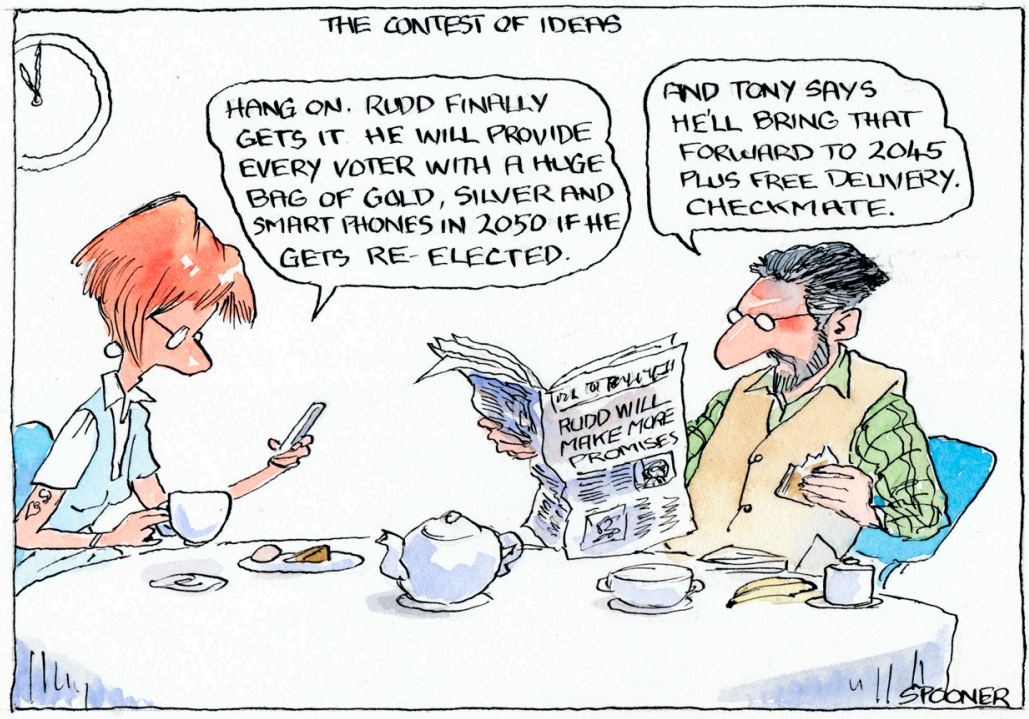

\section{Figure 4}

Source: John Spooner, The Age, 29 August 2013.

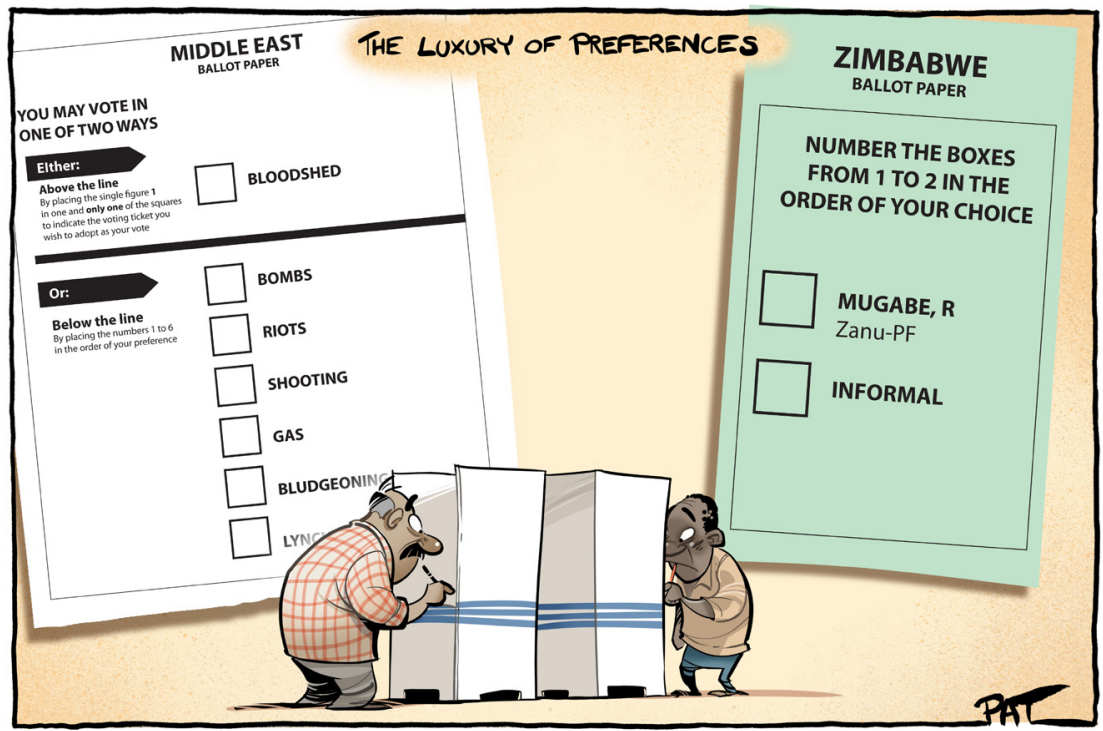

\section{Figure 5}

Source: Pat Campbell, The Canberra Times, 26 August 2013. 
With their mixture of vivid images and succinct words, political cartoons provide graphic islands in a sea — or perhaps we should say 'swamp' — of election campaign analysis. The point is, 'cartoonists draw on timely topics that have already been established in the mainstream media', and while they 'speak of the world in hyperfigurative terms, political cartoons are but one mode of opinion news discourse that enables the public to actively classify, organise and interpret what they see and experience in meaningful ways' (Greenberg 2002: 195).

It was noted at the beginning of this chapter that cartoonists tend to highlight issues of personality. Our main observation about the cartoonists' perspective on the 2013 campaign is that they viewed it as 'nearly all about Kevin'. The majority of cartoons focused on Rudd's campaign whereas Abbott escaped the satirists' close scrutiny. Perhaps Abbott's relentless work of demolishing Labor's credibility, abetted hugely by Labor's internal dysfunction, had blunted the cartoonists who, like the majority of voters, were transfixed by Labor's bitter internal divisions rather than the opposition's credentials. For those who hoped there would at least be some sort of contest, the realistic question was whether Rudd might campaign as he did in 2007 and 'save some of the furniture' or whether Labor was headed for a thrashing like those recently experienced by its New South Wales and Queensland branches. We begin by looking at the leaders' campaigns, starting with Abbott to test the proposition that little mud stuck to him. We then turn to what the cartoonists observed about some key issues, the minor parties, the Murdoch press and finally the result. Here too, the focus on personality remained a key theme, with Rupert Murdoch, Bob Katter and Clive Palmer being obvious additional targets for the cartoonists' tools of caricature and pithy comment.

\section{Abbott's script: 'Sex appeal', sexism and softening the caricature}

Labor had long sought to demonise Tony Abbott with some apparent success, as his 'net satisfaction rating' measured in Newspoll travelled deeply in the negative zone throughout his time as opposition leader; in fact worse than for most opposition leaders. However, as is usually the case, it improved once the campaign started (Brent 2013). Given the electorate's hostility to the ALP government, the main thing Abbott needed to do was avoid gaffes that might expose him to Labor's attack upon his Catholic conservatism and supposedly old fashioned and 'sexist' views of women. The cartoons (being sensitive gaffedetectors) show that he largely succeeded in this by making only a few mistakes that, crucially, didn't 'stick' as major impressions on public consciousness. For 
instance, Alan Moir's cartoon points to Abbott having surprised commentators, and arguably his own colleagues, by his disciplined approach and dogged capacity to stay 'on message'.

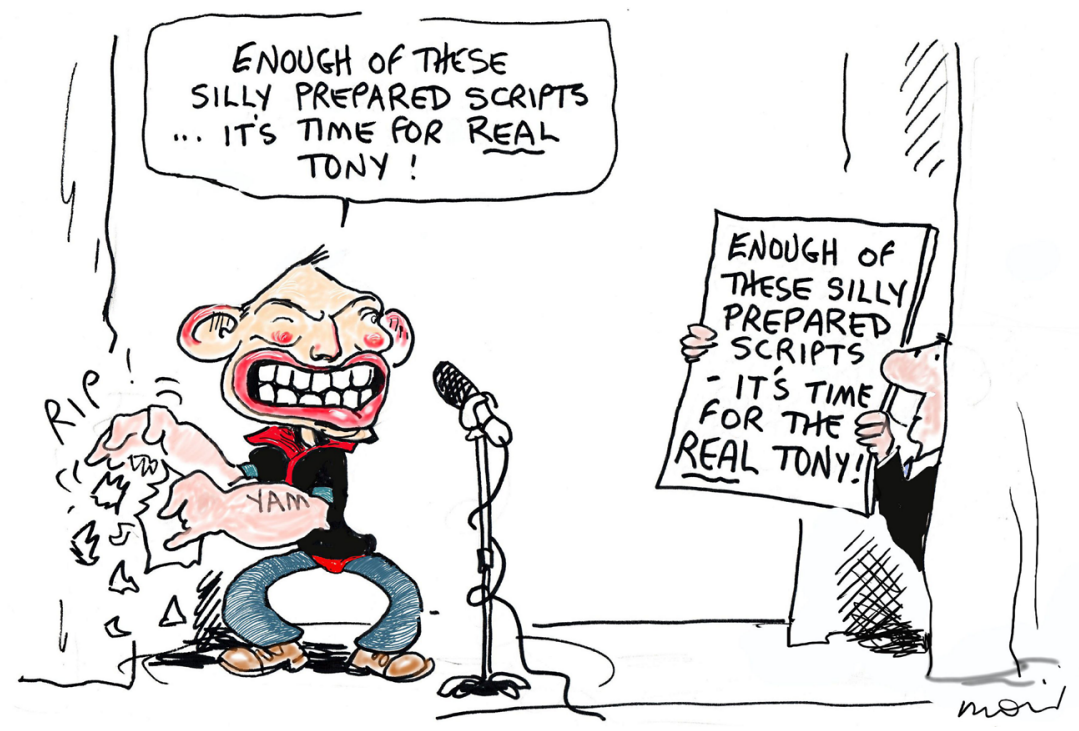

\section{Figure 6}

Source: Alan Moir, The Sydney Morning Herald, 12 August 2013.

As Pamela Williams observes, his campaign rested on the fact that he 'was disciplined, focused and operating comfortably in a framework where everyone had their eye on the same goal working from a unified script' (Williams 2013). The cartoon also alludes to a moment in the 2010 campaign when Julia Gillard announced that she would become the 'real Julia' rather than an overly stagemanaged leader. Cartoonists are quick to pick any lack of authenticity, and with leaders so much in the hands of campaign professionals and their daily messaging, Moir is also suggesting, almost sympathetically, how frustrating it must be to be so scripted. Long-time readers of Moir's cartoons (and much of the Fairfax press) will realise, however, that the tiny bit of sympathy is much outweighed by fear that the real Tony will come out after the election as an authoritarian muscle-man.

Early in the campaign's second week Abbott went off-script with a couple of gaffes, neither particularly serious, which featured across old and new media for a couple of days and offered Labor hope that more would follow. The first saw him misconstrue the English language while the other provoked debate over whether he was steeped in sexist views of women. Addressing the party faithful at the Liberals' campaign launch in the seat of Deakin, he took aim at Rudd's 
one-man-band approach to governing. Unfortunately a slip of the tongue, or perhaps a leap of logic, had him say, 'No-one, however smart, however welleducated, however experienced, is the suppository of all wisdom, and I believe that we will be a much better government because we have a very strong team'. Of course he meant to say 'repository' and for his trouble within half an hour someone inaugurated a Twitter hashtag \#suppository accompanied by photoshopped images with suppository-inspired captions ('know your enema', 'squeezing out a policy', etc). It trended quickly as a tweet and featured in the nightly news bulletins. The phrase featured in a number of cartoons and in other comic modes but it did no lasting damage, partly because it was merely an isolated slip of the tongue (so people could identify with Abbott) and perhaps also because it worked as a joke that confirmed a low public assessment of the wisdom of politicians.

Later in the day, while campaigning in the Western Sydney seat of Lindsay, Abbott made a potentially more dangerous slip. A journalist asked him how Liberal candidate Fiona Scott compared with former Liberal MP Jackie Kelly, an innocuous question which solicited this response: 'They're young, feisty, I think I can probably say have a bit of sex appeal and they're just very connected with the local area'. In the charged atmosphere since Julia Gillard's 'misogyny' speech of October 2012, this clearly risked fuelling the view that Abbott was sexist. Cartoonists and politicians waded in.

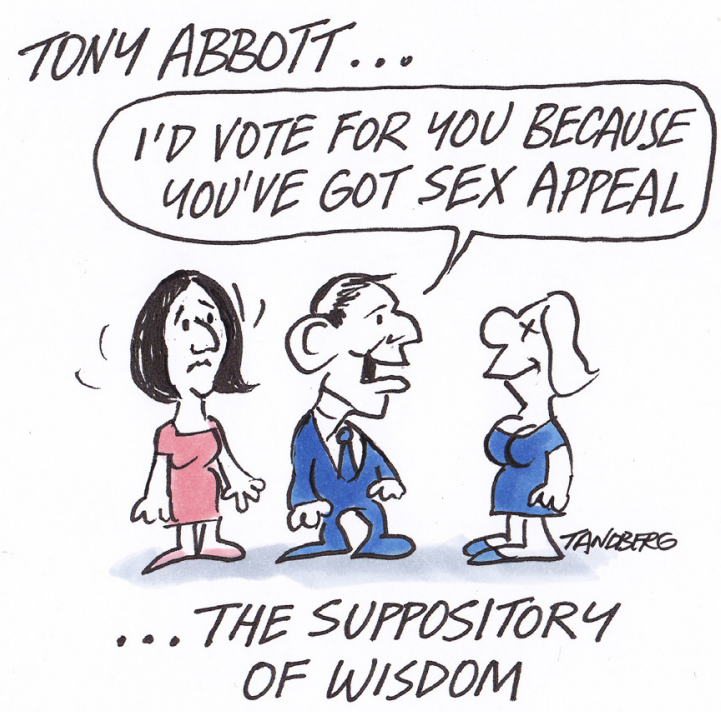

\section{Figure 7}




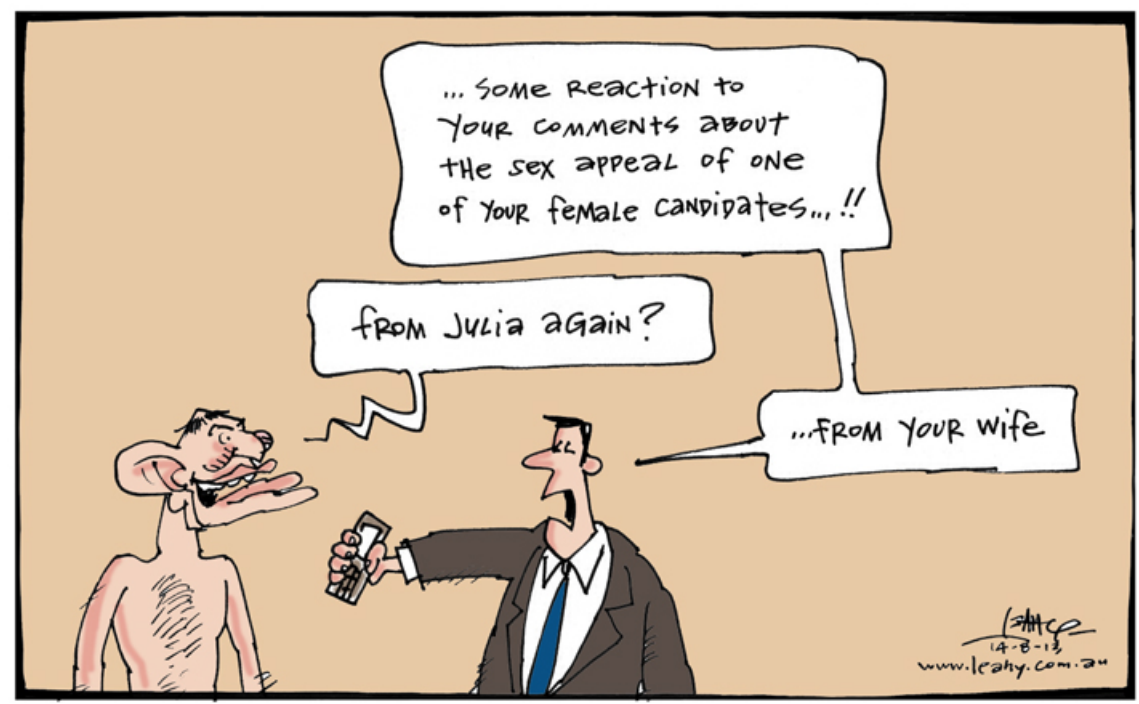

Figure 8

Source: Sean Leahy, Courier-Mail, 14 August 2013.

Rudd described the comment as 'odd', while Labor frontbencher Kim Carr seized upon it saying, 'He's pathetic, he really is pathetic ... Sometimes we should think Tony Abbott really hasn't crawled out of the 1950s'. Coalition women like New South Wales minister Pru Goward, a former sex discrimination commissioner, leapt to his defence. His own daughter, who was standing behind him at the time and was heard to gasp, later described her father's statement as a 'daggy dad moment'. Savaging Abbott as 'superficial and sexist', Greens leader Christine Milne asked, 'Why didn't he talk about professionalism or policy or intellect?' (Ireland and Swan 2013).

Abbott's 'sex appeal' gaffe highlighted the only real question mark over the Coalition's campaign, namely Abbott's 'problem with women'. Certainly the problem didn't derail his campaign - as his opponent had just defeated the nation's first female prime minister in a bloody party-room ballot, there was a limit on how far the argument could be pressed-but the Coalition campaign made clear and obvious moves to neutralise the risk. Whether it was planned months before the campaign we do not know, but the Liberals' campaign launch was very much directed at debunking the view that there was ever a problem. Two of Abbott's daughters, Frances and Bridget, introduced him to the party faithful, and their tightly scripted words sought to dispel any notion that their father was sexist, let alone a misogynist. The imagery was analogous to 
Obama's campaign style (Joye 2013) as it celebrated these alpha women's efforts to convince voters, who may have harboured doubts about their father's values, to reconsider.

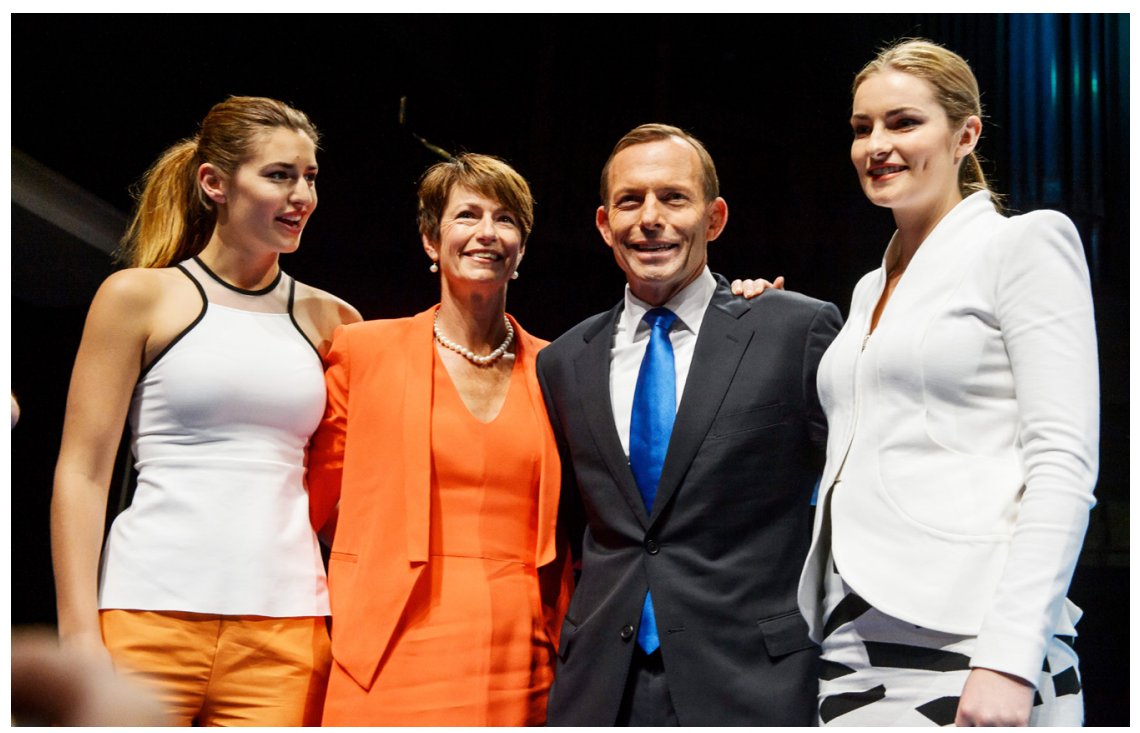

\section{Figure 9: Tony Abbott with wife Margaret and daughters Bridget and Frances at the Coalition's campaign launch in Brisbane}

Source: Herald Sun. Picture: Jay Town.

TV bulletins and front pages led with his daughters, driving home the message Liberal HQ desired with phrases like these from his daughters' script: 'I've seen my Dad with people from all walks of life-young, old, rich, poor, gay, straight, the frail, the fit, indigenous and migrant, and he treats every single one of them with equal respect'; and, 'My dad looks out for everyone and I know he will look out for you'. Toward the end of the campaign Abbott appeared on the Nine Network's show Big Brother, where, sitting alongside his daughters, he urged contestants to vote for him because he was the one with the 'not bad looking daughters'. David Rowe presents the Liberal campaign's use of the daughters as an insult to voter intelligence in this memorably grotesque image.

It seems likely that this issue was never going to change many minds. Those who thought Abbott sexist were already opposed to him and in the 'old Australia' where much of the 'rusted-on' Liberal vote resides, such attitudes were seen as fairly reasonable. The following cartoon from Mark Knight may imply this, but it may also suggest that Abbott would be uncomfortable with a gender role reversal in which he was sexually objectified, with an older unappealing geriatric commenting on the sex appeal of the younger man. 


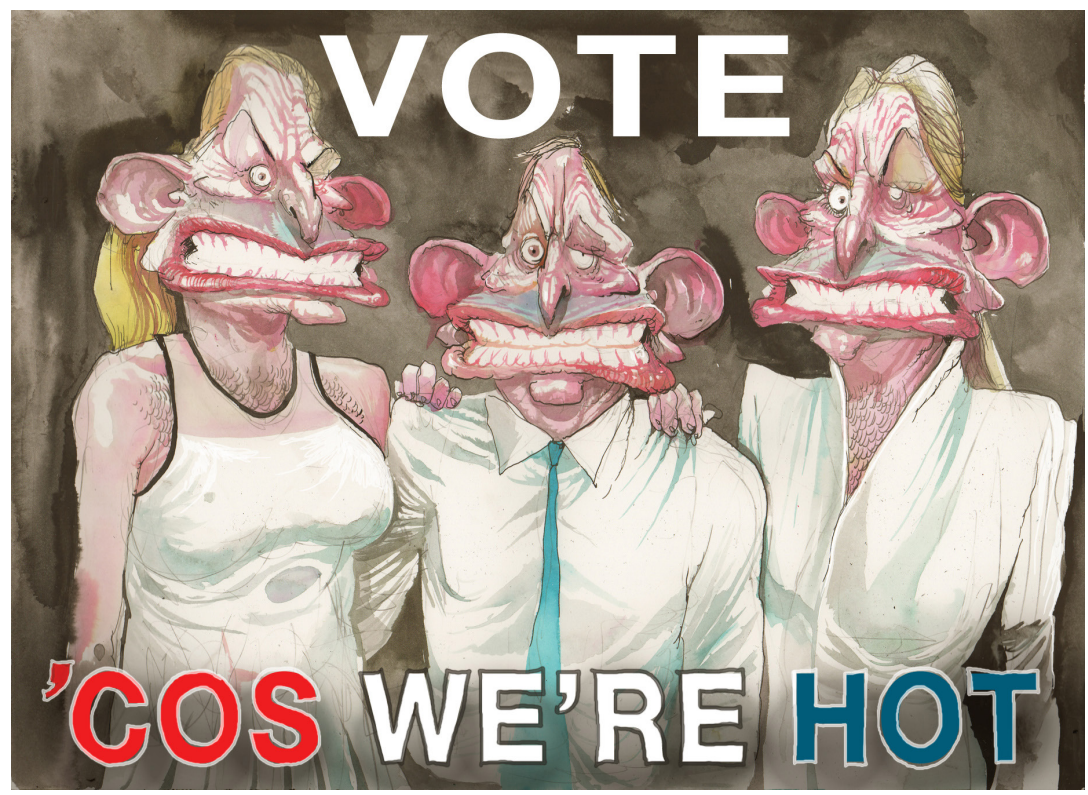

Figure 10

Source: David Rowe, Australian Financial Review, 5 September 2013.

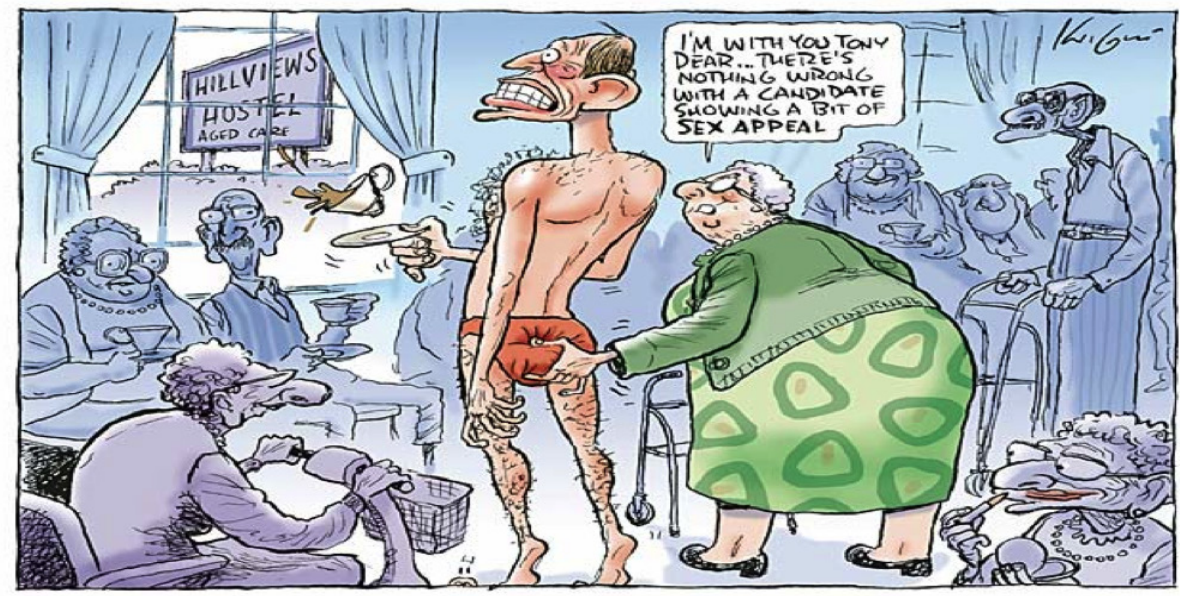

Figure 11

Source: Mark Knight, Herald Sun, 15 August 2013.

As Knight's further cartoon on Abbott's personally championed paid parental leave scheme suggests, several constituencies were prepared to avert their gaze from problems in his profile simply in order to get rid of the other mob: 


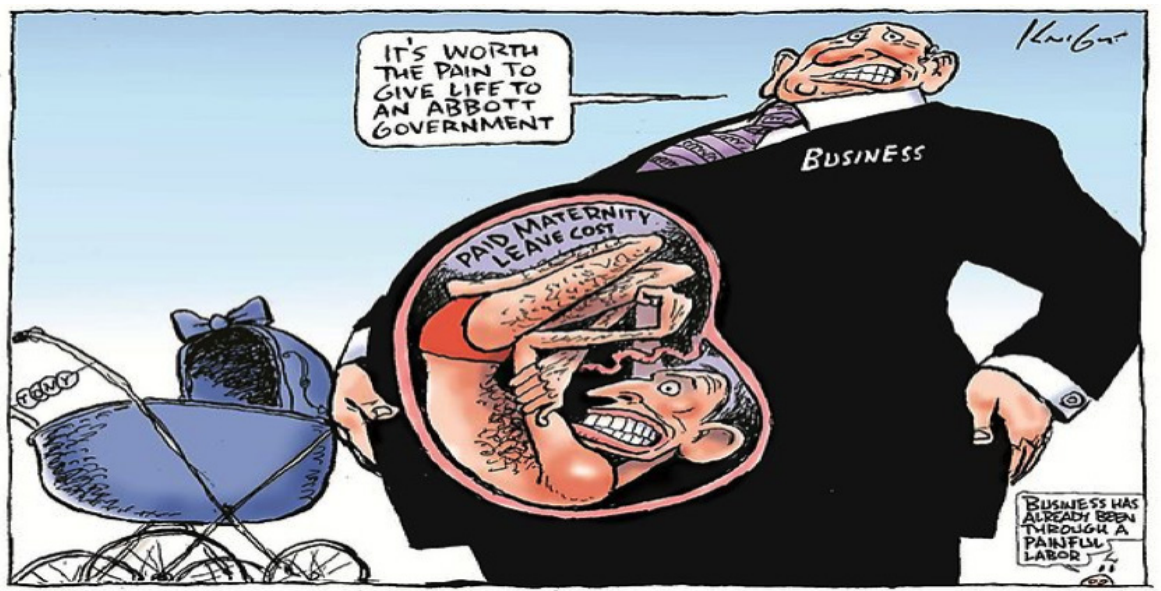

Figure 12

Source: Mark Knight, Herald Sun, 19 August 2013.

\section{Rudd's chaotic burnout}

Labor's principal aim in this campaign was realistically about damage control and how Kevin Rudd, who had campaigned so brilliantly in 2007, could deliver a respectable loss. In the inner group travelling with the restored PM, there was more optimism about a possible victory and this tension between realists and dreamers caused mounting trouble as the campaign wore on. The Gillard government's last months saw Labor's primary vote in the polls sink so low that a generation of future Labor leaders faced defeat, and being reduced to only 30 seats in the next parliament seemed a serious possibility (Wright 2013). Labor began 2013 with some hope, but the rot set in once the aborted leadership challenge unfolded in March. This cartoon captures well the farcical events when former leader Simon Crean backed Rudd to challenge, only to find him unwilling to front. Gillard was tactically devastating and then ruthless in victory to the former ministers represented here decapitated on pikes.

Then, in June, Rudd won the party room ballot and felt redeemed. Shockingly close to an election, the Labor campaign required reinvention and new staff as many Gillard supporters departed. Much would depend on Rudd's capacity to present a focused and disciplined campaign, but he had few policy successes to tout and a millstone of critique from within Labor ranks. With crude headlines in the Murdoch press calling for Labor's demise, Rudd complained of bias, and Bill Leak, who in 2007 characterised Rudd as the youthful and hopeful 
Tintin, now presented a far harsher view of the resurrected prime minister as a grotesque and vengeful Narcissus obsessed with his own image or a Dorian Gray keeping his true nature hidden from public view.

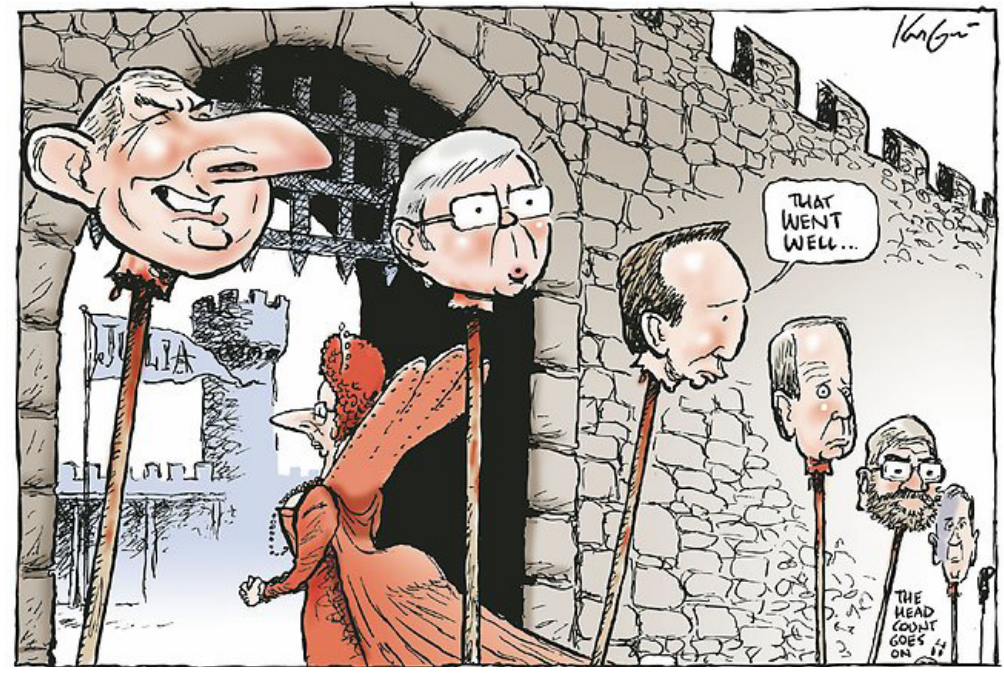

Figure 13

Source: Mark Knight, Herald Sun, 23 March 2013.

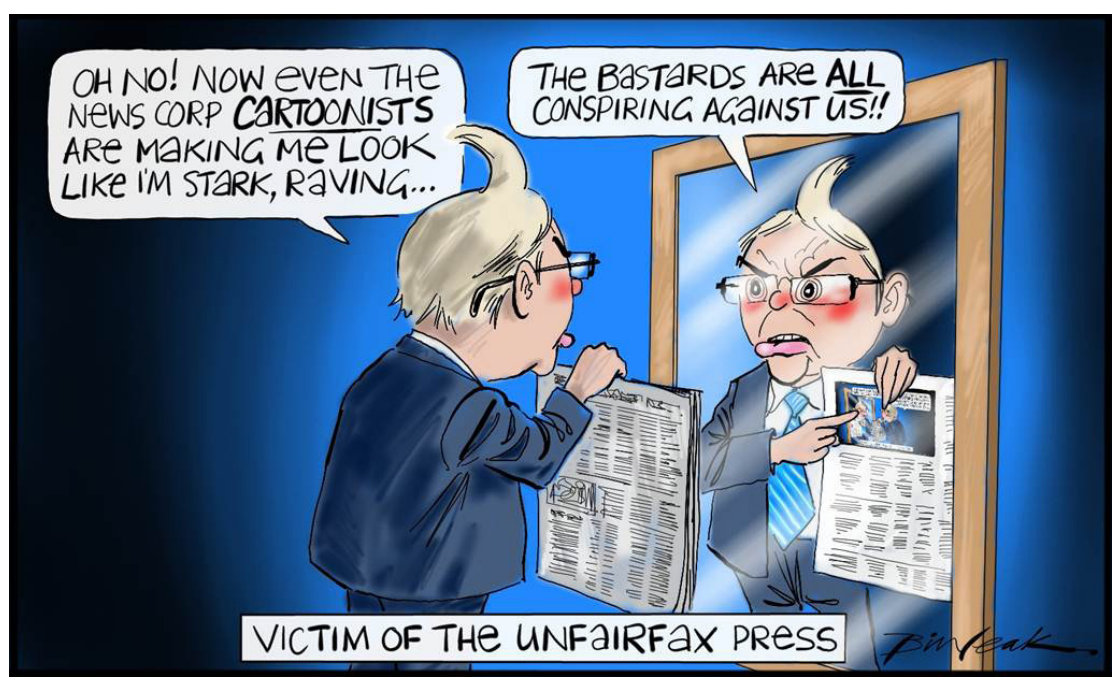

Figure 14

Source: Bill Leak, The Australian, 8 August 2013. 
Leak was clearly the most critical of the cartoonists, with most of his cartoons aimed at lampooning what he saw as Rudd's dysfunction and propensity to narcissism, but other cartoonists also drew upon these themes. Upon returning to the prime ministership Rudd promised a 'New Way' and 'New Politics' and when that was exposed as hollow he sought to demonise his opponent with images of a government likely to embrace austerity and raise the GST. Leak suggests voters would smell the rat when Rudd did a set piece media stunt with a jar of Vegemite arguing its price would increase under Abbott's secret plan to increase the GST.

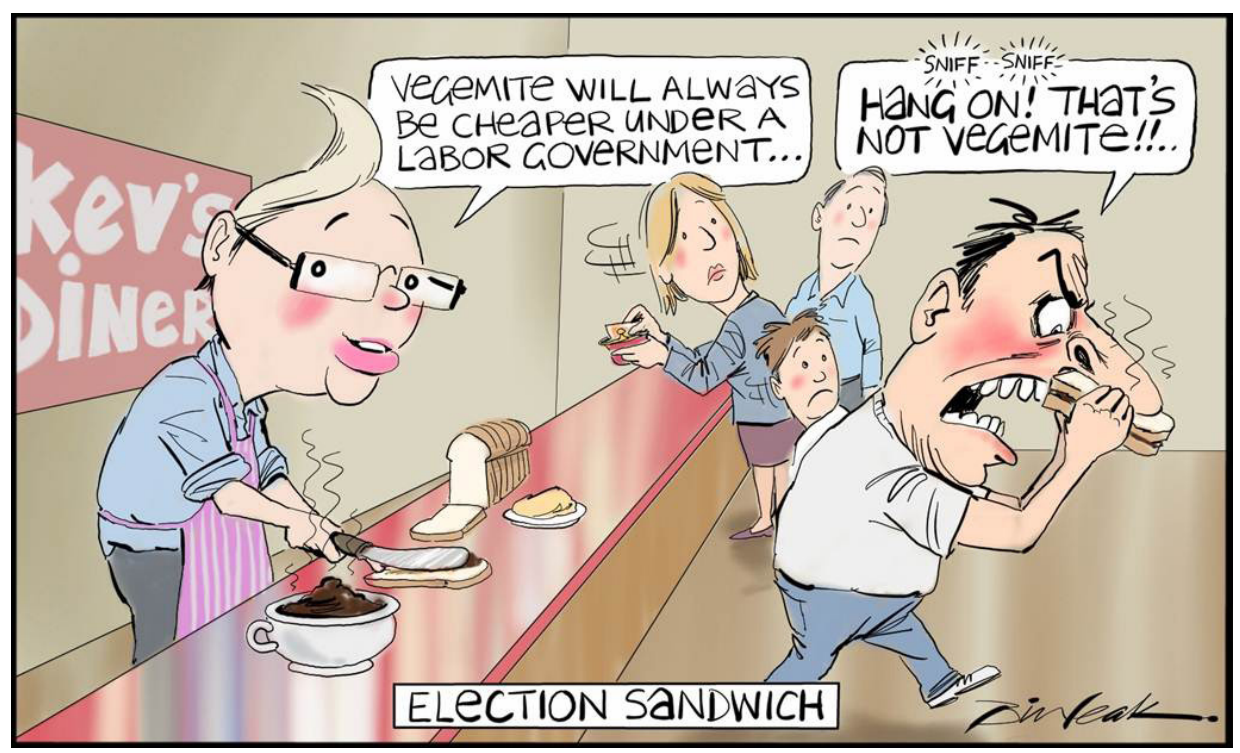

Figure 15

Source: Bill Leak, The Australian, 12 August 2013.

When Labor turned to former Queensland premier Peter Beattie to run in the Liberal-held marginal seat of Forde, the sense of an ill-considered campaign began to fester. Political recycling rarely gains traction and David Rowe's caricature of Beattie catches him poised between success and failure, either as a cane toad about to derail Abbott's campaign or caught in the headlights of his cruise to victory. Ultimately voters were not impressed and, after an initial flurry of excitement, little was heard from Beattie as his chances sunk.

Why did Rudd's campaign appear so chaotic? Charitable opinion might argue Rudd had little time to prepare a campaign based on his policy priorities, plus he needed to distance himself from the Gillard legacy and the stench of chaos and corruption in state ALP branches, especially New South Wales where Alan Moir focuses this powerful cartoon: 


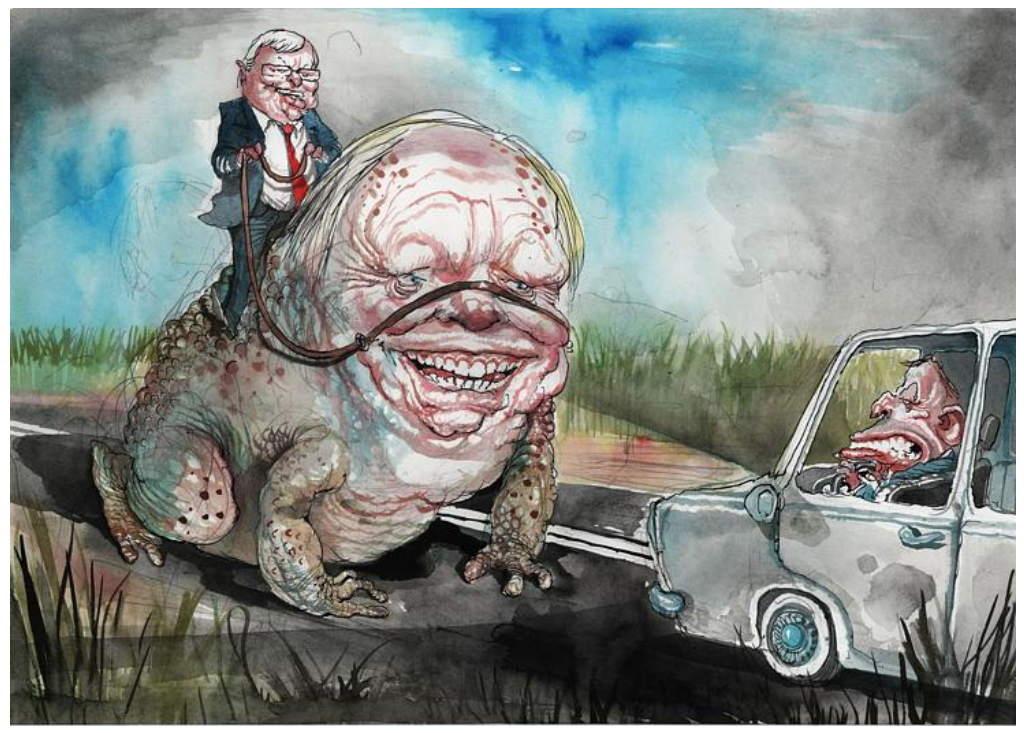

Figure 16

Source: David Rowe, Australian Financial Review, 9 August 2013.

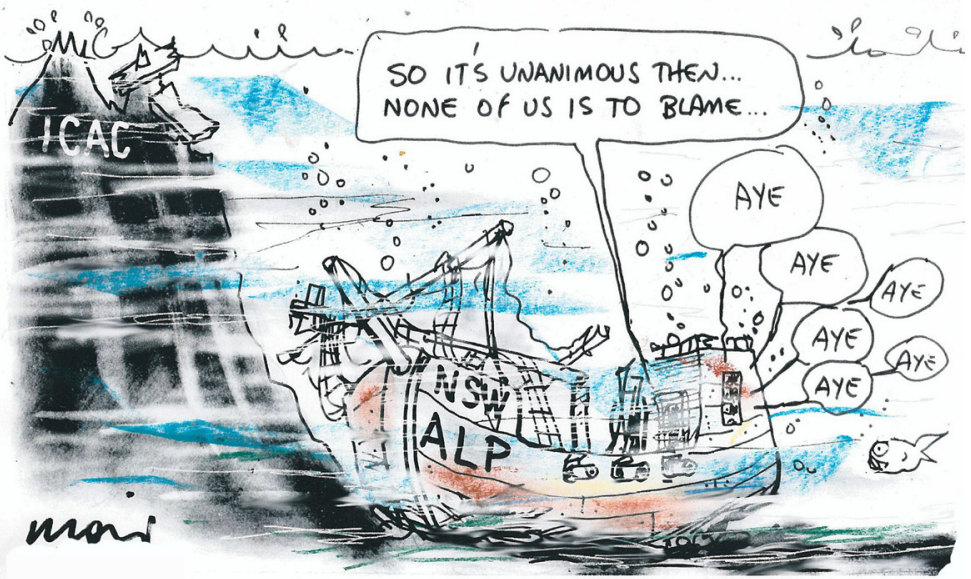

Figure 17

Source: Alan Moir, The Sydney Morning Herald, 3 September 2013.

Little wonder nothing seemed to work and, by the end of August, Leak depicted an embattled Rudd sinking in a sea of sharks, sending up increasingly desperate thought bubbles. 


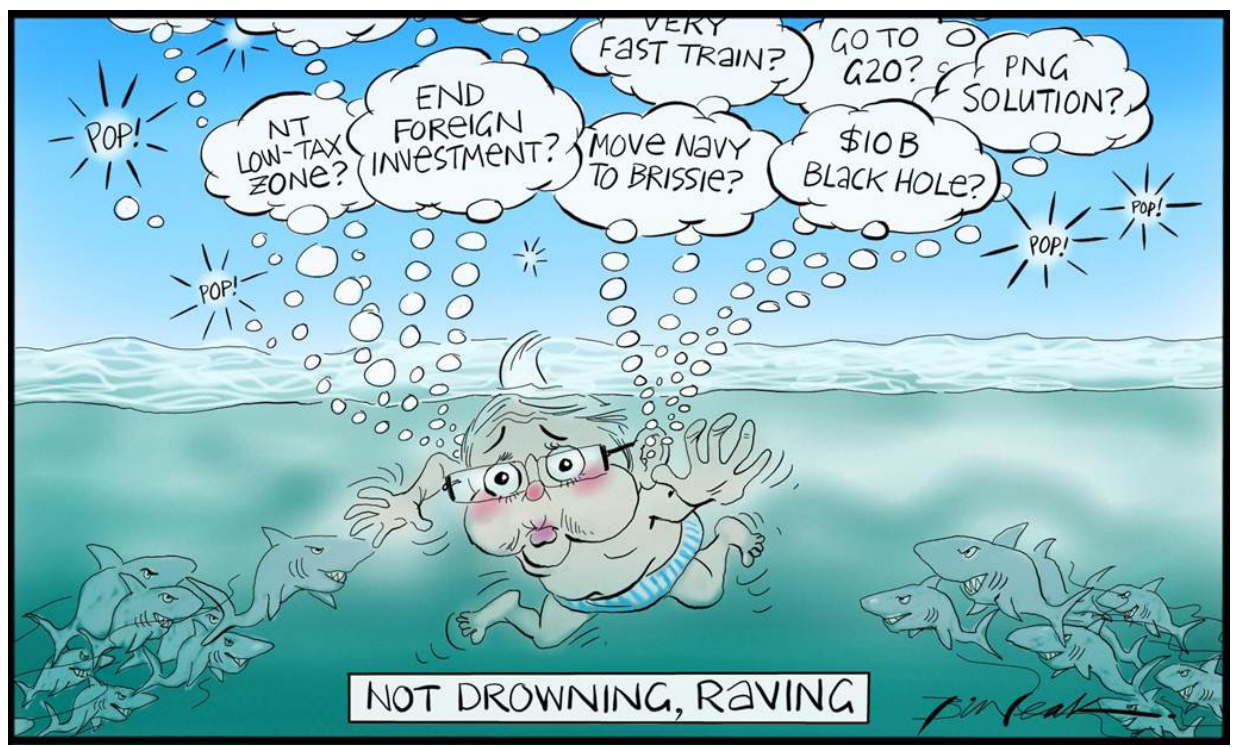

Figure 18

Source: Bill Leak, Australian, 31 August 2013.

Policies were announced without the Melbourne-based campaign office being prepared, let alone the stakeholders involved. Leak's cartoon certainly reflects what leading members of the commentariat wrote post-election (Bramston 2013; Snow 2013; Williams 2013) and is best highlighted by two clear examples of policy by thought bubble: the northern Australia lower tax zone and the proposed movement of naval forces from Sydney Harbour to Queensland.

The headline-grabbing policy of 'Growing the North' with special tax concessions for businesses in the Northern Territory lacked detail and, worse, it was basically the same as a policy Abbott had announced in June that Labor had criticised when Gillard was leader. It quickly fell flat and Mark Knight depicts Rudd strolling into the jaws of a dilemma holding little more than a lamp for guidance:

Williams (2013) succinctly observes that, 'Proposals such as a changed economic zone for the Northern Territory had no resonance in the general campaign message and instead became the subject of ridicule'. Rayner and Wanna (Chapter 1) point to the Coalition's effort to portray Rudd as unelectable due to his 'manic edge':

One of the Coalition's cut-through campaign messages of 2013 which tagged Kevin Rudd as 'Captain Chaos' had its genesis in this earlier period, when it seemed as though the energy and enthusiasm of 2007 had acquired a more manic edge. 


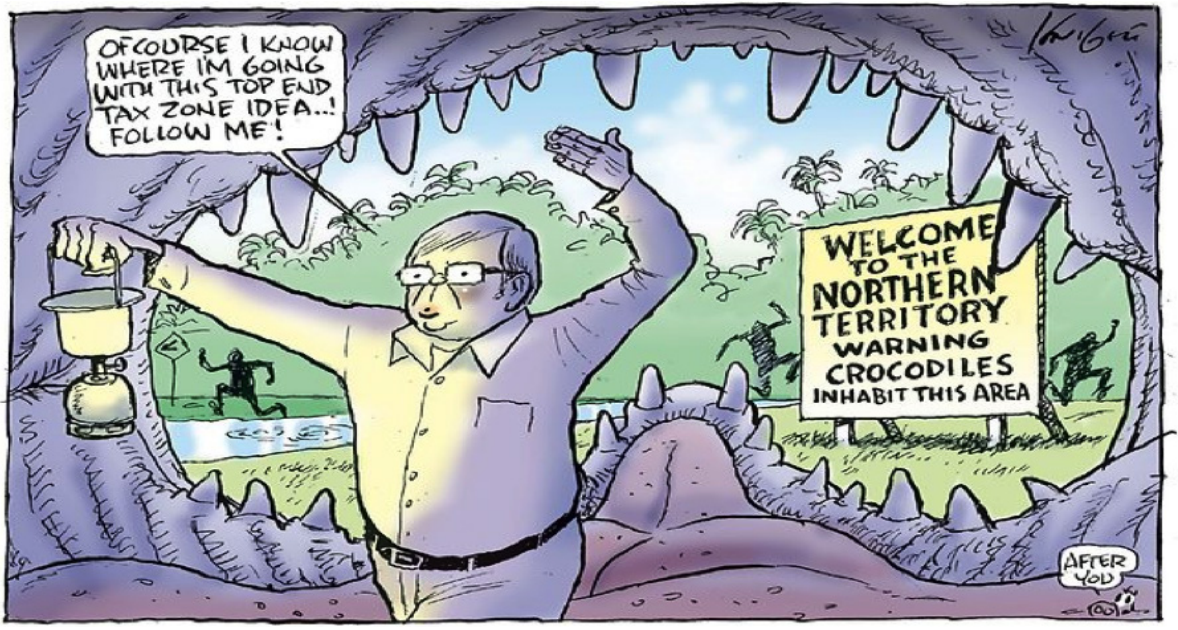

\section{Figure 19}

Source: Mark Knight, Herald Sun, 17 August 2013.

Cartoonists picked up on this aspect as illustrated by Warren Brown's pointed critique of the planning behind the proposed transfer of naval forces:

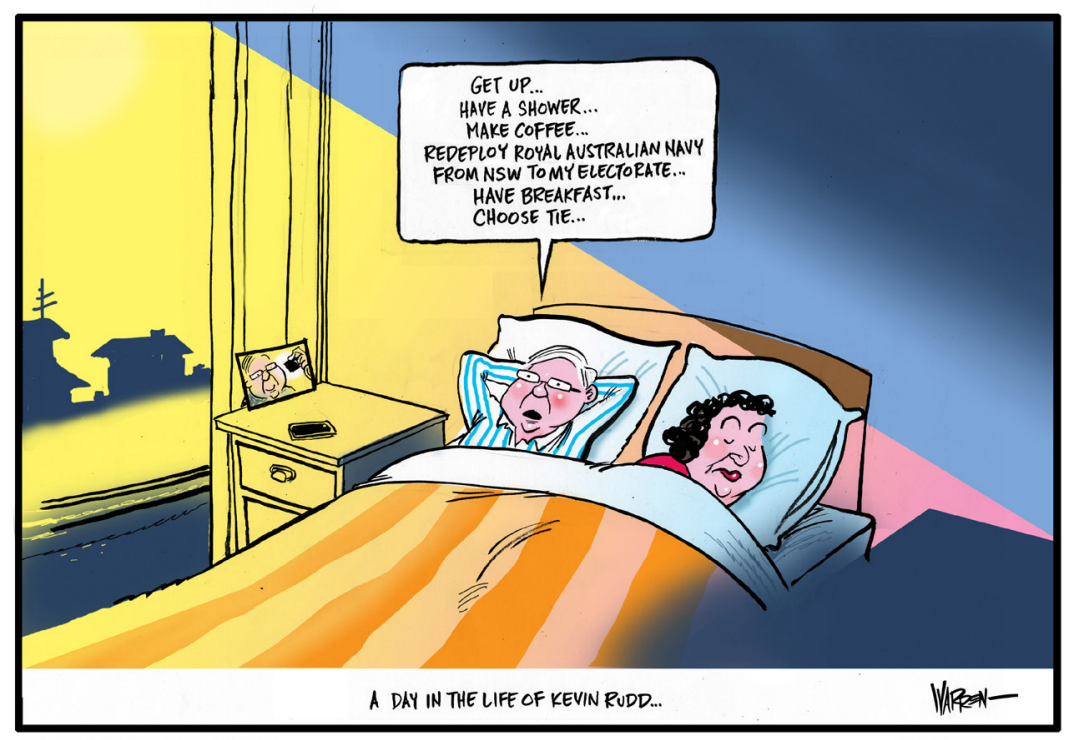

Figure 20

Source: Warren Brown, Daily Telegraph, 29 August 2013. 
While Rudd's first week of campaigning went well and he performed marginally better than Abbott in the three leaders' debates, there remained throughout a 'curious sense that Rudd was performing as an opposition leader rather than an incumbent PM, complaining about the Coalition and (fruitlessly) demanding that Abbott answer his questions'. Abbott seemed always in control and Rudd forever keen to try and scare voters with what Abbott might do in government. All this played to the 'Captain Chaos' stereotype that Rudd's opponents within the ALP had done so much to propagate, and the cartoonists helped this impression gel in the minds of voters. Rudd's final days on the campaign trail seemed little more than endless crowds of young Labor recruits taking 'selfies' with Kevin. Mark Knight turned this into an election eve cartoon that encapsulates much about the man who caused, over the previous three years, so much electoral damage to his party.

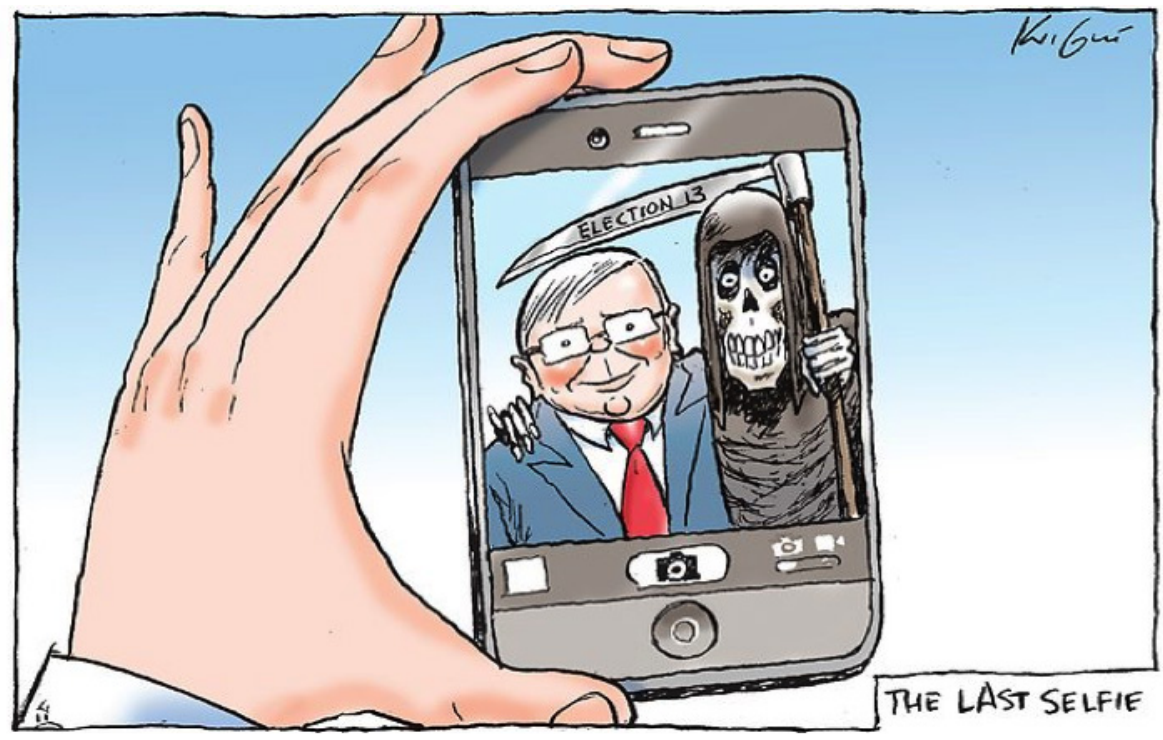

\section{Figure 21}

Source: Mark Knight, Herald Sun, 6 September 2013.

Jon Kudelka sums up the entire resurrection experiment almost wistfully. Rudd was an Icarus whose wings had melted in the heat of the Labor party room in 2010. Now they were melting again in the heat of the 2013 election. At no point had the promise of 2007 been fulfilled.

Late in the campaign, Labor's gamble in changing leaders yet again was unravelling with little evidence of the 'New Way' Rudd had promised at the campaign's outset. All he had left in the end was the claim that he had done it all to save Labor from a catastrophically deep defeat. 


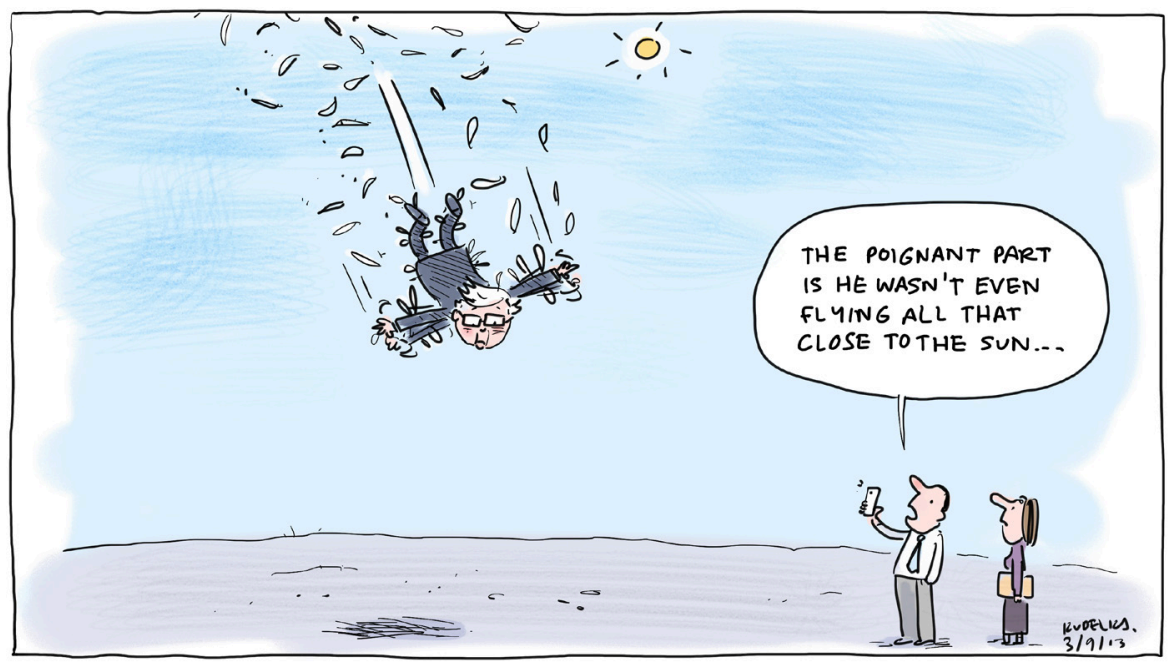

\section{Figure 22}

Source: Jon Kudelka, The Australian, 3 September 2013.

\section{Key issues and minor parties}

Asylum seekers were an issue in the 2013 campaign but for the cartoonists they presented a much more confusing issue than they had in previous elections, especially the 'Tampa election' of 2001. At that time both leaders, Howard and Beazley, took a tough line but the cartoonists took the moral high ground and produced some searing satire (Manning and Phiddian 2002). Twelve years later the issue had become more complex as deaths at sea mounted and the people smugglers seemed untouchable. Labor's harsh deterrents to 'boat people' mirrored the Coalition's policies and only the Greens remained steadfast with their assertion that such policies were 'cruel' and 'immoral'. The closest we came to a cartoon with the force of 2001 is Wilcox's effort to chastise two devoutly Christian leaders on what she sees as a range of hypocrisies. But even this pales against what we have viewed in the past and the decline in the Greens vote is possibly also an indication that this issue is no longer straightforward for those with a 'bleeding heart'. 


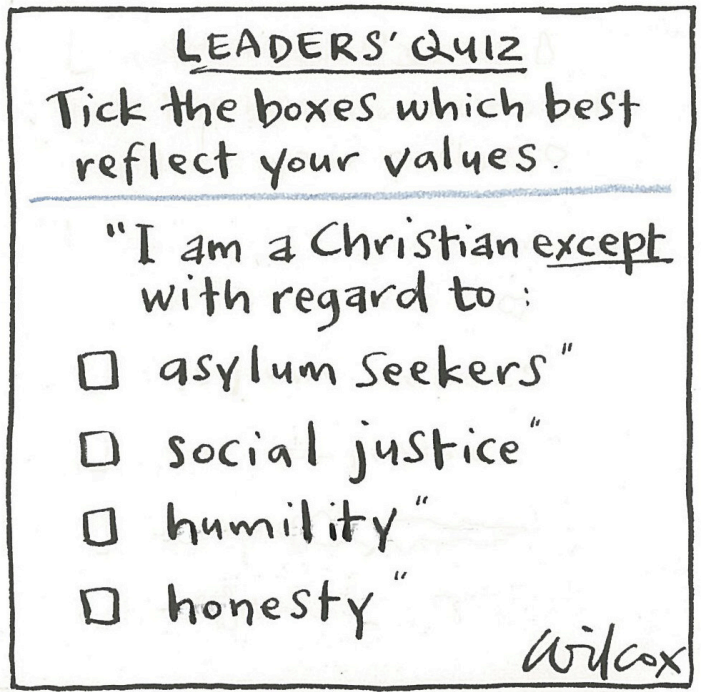

\section{Figure 23}

Source: Cathy Wilcox, The Sydney Morning Herald, 2 September 2013.

The elephant in the election campaign room is often the question of where the money to pay for promises is coming from. This was an even bigger issue than usual because there was so much squabbling and mutual accusations of hypocrisy. Sean Leahy ponders the matter after the final leaders' debate:

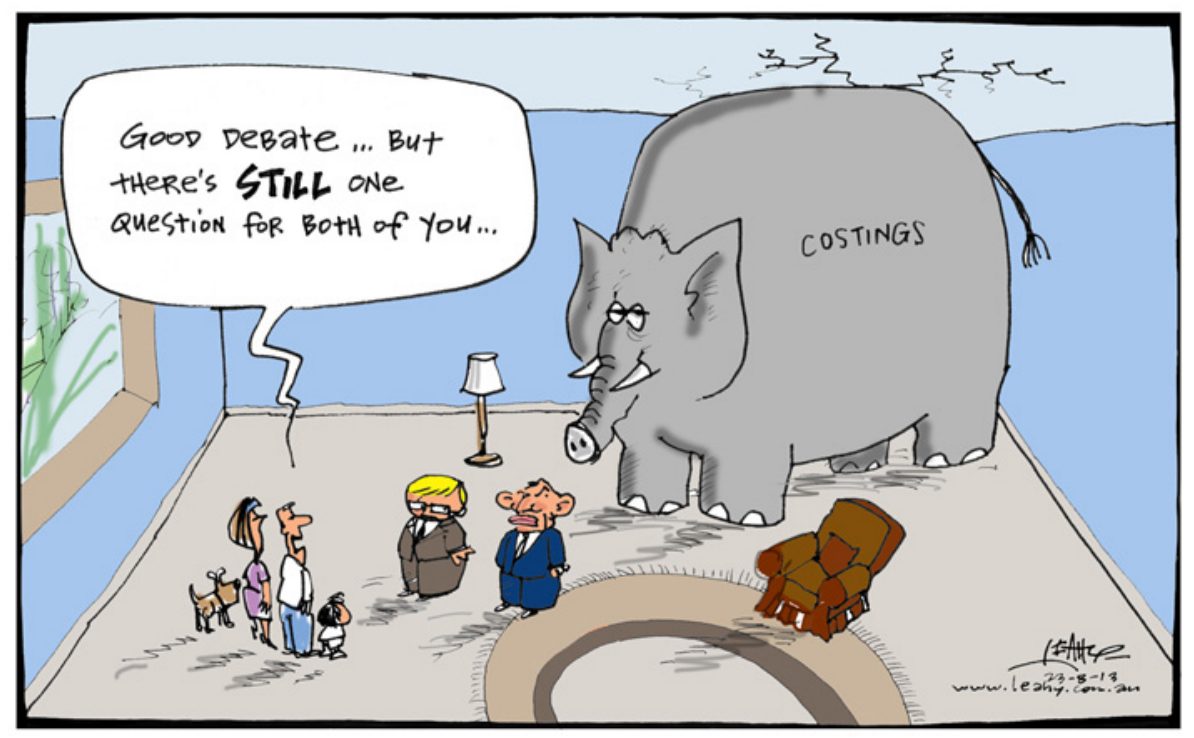

Figure 24 
As is now customary, it was only in the dying days of the campaign that the opposition released its calculations and by that point the issue was no longer a potential vote changer. Had Labor managed to earn a reputation for fiscal coherence in six years of government this may have played out differently, but voters and cartoonists seem not to have felt there was much between the parties on probity.

From the start of the campaign, the Murdoch press presented a level of hostility toward Labor that surprised some, including Kevin Rudd himself (Williams 2013). This is covered in Errington's chapter so we will not analyse it here; the point is that cartoonists working outside of the News Limited newspapers certainly took the opportunity to comment. Peter Broelman amuses readers with a sense of history when he parodies the 'Mongolian Octopus' image first drawn by cartoonist Phil May for the Bulletin Magazine in 1886. May's image was racist and aimed at warning Australians of the 'Asian Peril' with the Octopus's arms carrying slogans such as 'Fan-Tan, 'Opium', 'Small Pox' and 'Cheap Labour'. Broelman's grisly Rupert Murdoch acts as a warning to voters to beware his newspapers' propaganda power, something the social activist organisation GetUp! also commented on in a crude but funny sketch/commercial. They sought to pay for wide public exposure on commercial television but found the networks reluctant to accept their money. ABC TV's program Media Watch (2013) gave it an airing and YouTube also ensured it received wider circulation.

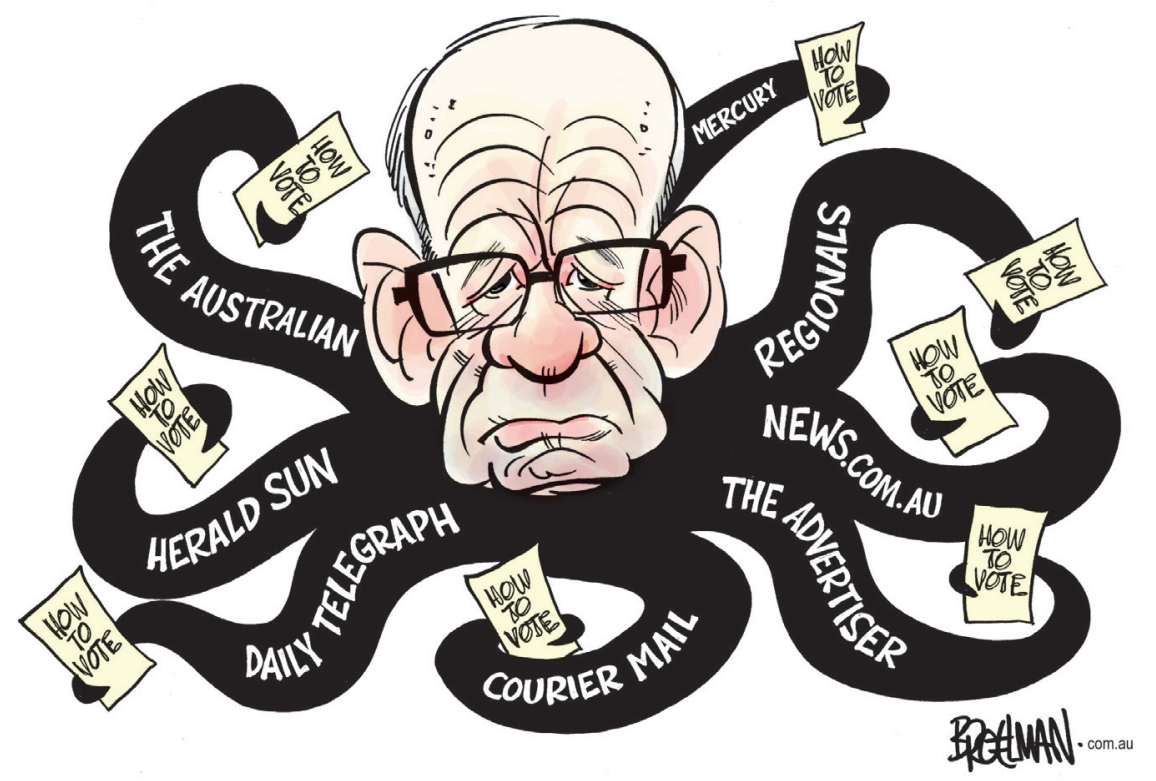

Figure 25

Source: Peter Broelman, Fairfax Syndication and APN regional press, 15 August 2013. 
With so much voter disaffection, the minor parties became a haven for disaffected voters and one big man with a gift for comedy played a particularly big role. Queensland-based billionaire mining magnate and resort owner Clive Palmer blasted himself into Election 2013 with unprecedented campaign spendingpossibly as high as $\$ 12$ million - and big boasts when interviewed on current affairs shows that he would win Fairfax in Queensland and at least two Senate places in Queensland, Tasmania and Victoria as well as at least one New South Wales Senator (Kelly 2013). Palmer was a figure of fun in cartoons and on the commercial television program Wednesday Night Fever, ${ }^{1}$ but he used this notoriety cleverly to garner free publicity on morning infotainment television programs and even in a sketch he scripted, sending himself up on national television. ${ }^{2}$ Clearly, he was underestimated by the political commentators and in this cartoon by Bill Leak, but neither can be particularly blamed for never has an Australian spent so much money or hyperbole in pursuit of elected office.

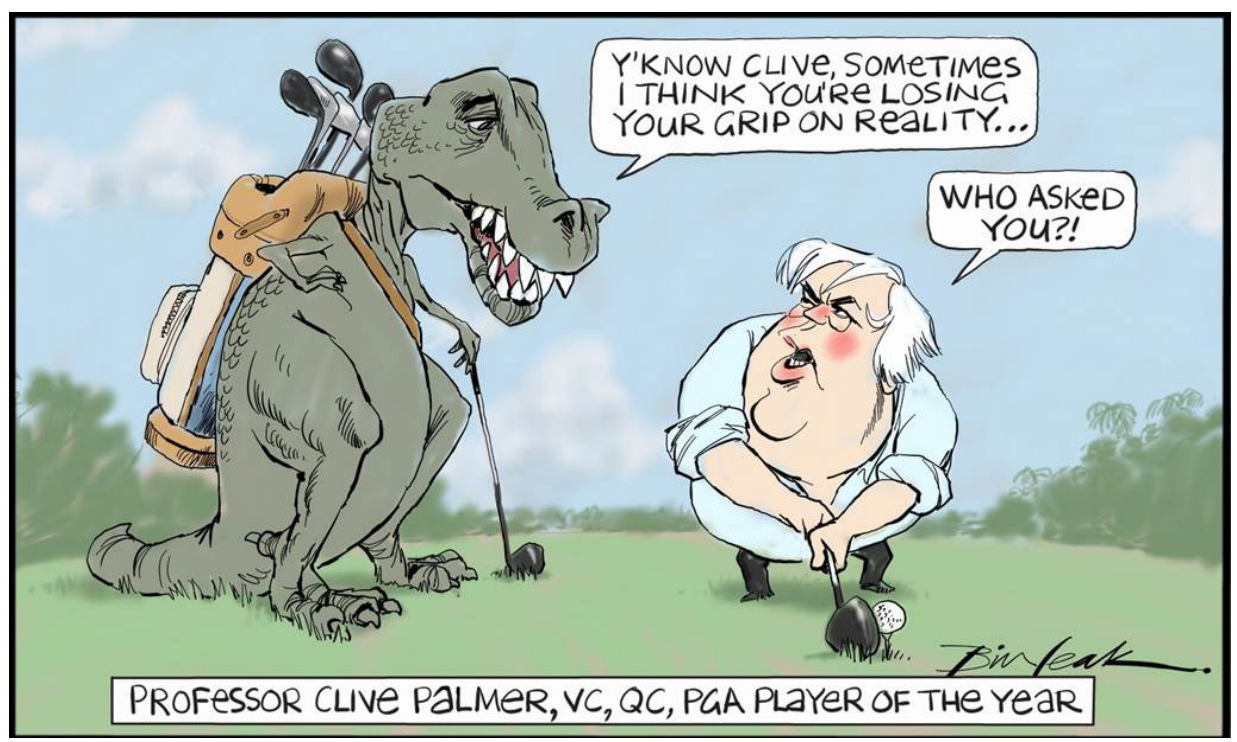

Figure 26

Source: Bill Leak, The Australian, 6 September 2013.

Katter's Australia Party (KAP) was the immediate victim of the Palmer United Party's emergence on the right wing of national politics. Party founder and member for Kennedy, Bob Katter is renowned for wearing a large hat and had been the consummate anti-politician of Australian politics. A large part of the story of the failure of KAP to become a force lies in Palmer's money and talent for

$1<$ www.youtube.com/watch?v=-_j34T5WNiE $>$.

$2<$ www.youtube.com/watch? $\mathrm{v}=$ chrIvuLSOMg $>$. 
populism, but a cartoon by Sean Leahy focuses on a sneaky political deal that may have tarnished Katter's image as an honest broker. Katter struck a deal to exchange preferences with Labor in a host of marginal seats in return for Labor's support in the Senate - Labor placed KAP ahead of all other parties. Katter tried to keep the preference decision 'secret' but this ended when an outraged KAP candidate, Paul Hunter, informed local media (Scott 2013). Sean Leahy very early in the campaign gave weight to the rumours that he was talking to Labor.

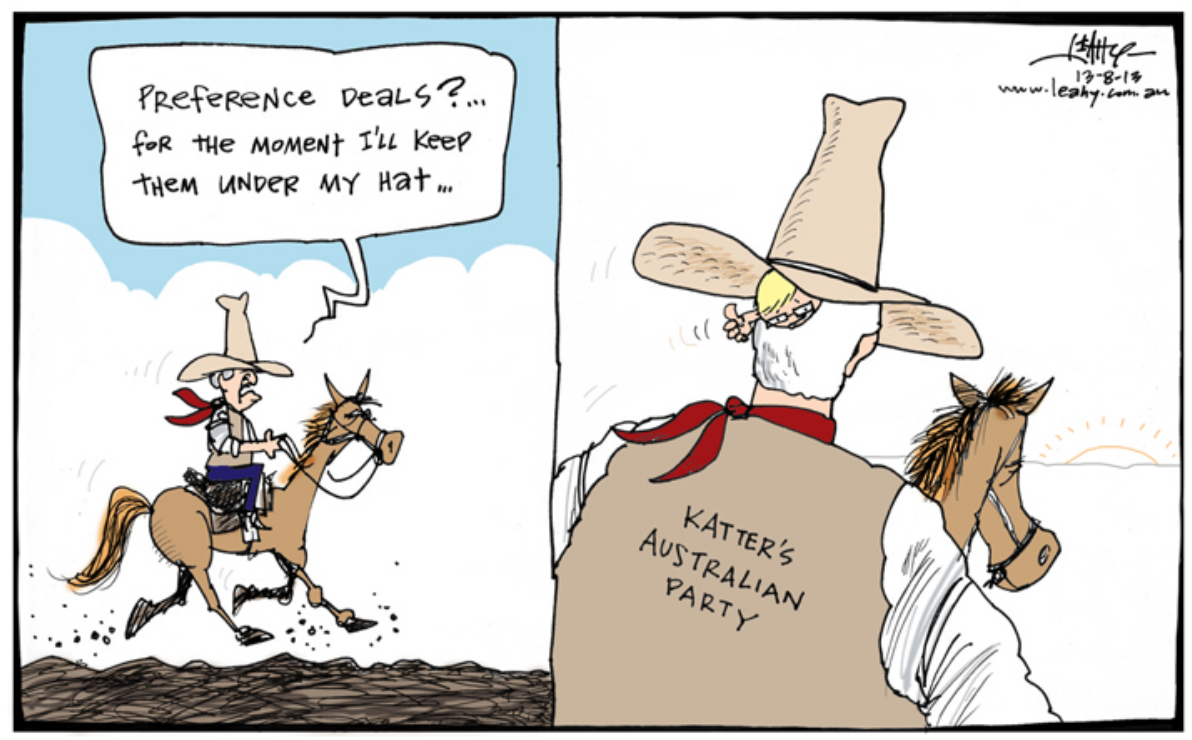

Figure 27

Source: Sean Leahy, Courier-Mail, 13 August 2013.

Katter was returned in Kennedy but his primary vote declined by 17 per cent, arguably in large part due to his efforts to do a 'secret deal' with Labor and because Palmer's candidate kept Katter's out of the Senate.

\section{Victor and vanquished}

When Tony Abbott defeated Malcolm Turnbull for the Liberal leadership in December 2009 by a solitary vote few considered him a genuine contender; he was just another prime ministerial hopeful likely to be replaced after Labor secured its second term. Labor MPs and most of the political commentariat believed him simply unelectable; the less charitable dubbed him the 'Mad Monk'. If Kevin Rudd had demonstrated the emotional intelligence required to lead a fairly united cabinet, Abbott's time as leader would likely have been short. To the surprise of many, Abbott managed to unite his party by relentlessly 
attacking Labor's 'faceless men' as a reflection of the party's dying organisational culture. Discipline became his calling card and he was constantly the recipient of chaotic leadership and policy making from a Labor Party that mistook activity for achievement. His rare feat was to undo three Labor prime ministers due to his relentless focus on their frailties. While at least three cartoonists represented his long march to victory with an image of red budgie smugglers flying over Parliament House, we think Matt Golding's neat depiction of his triumph rewards more careful attention. Abbott had repeatedly said winning office from opposition was akin to climbing Everest; and here he is standing on a defeated sphinx-like Rudd in the Himalayas.

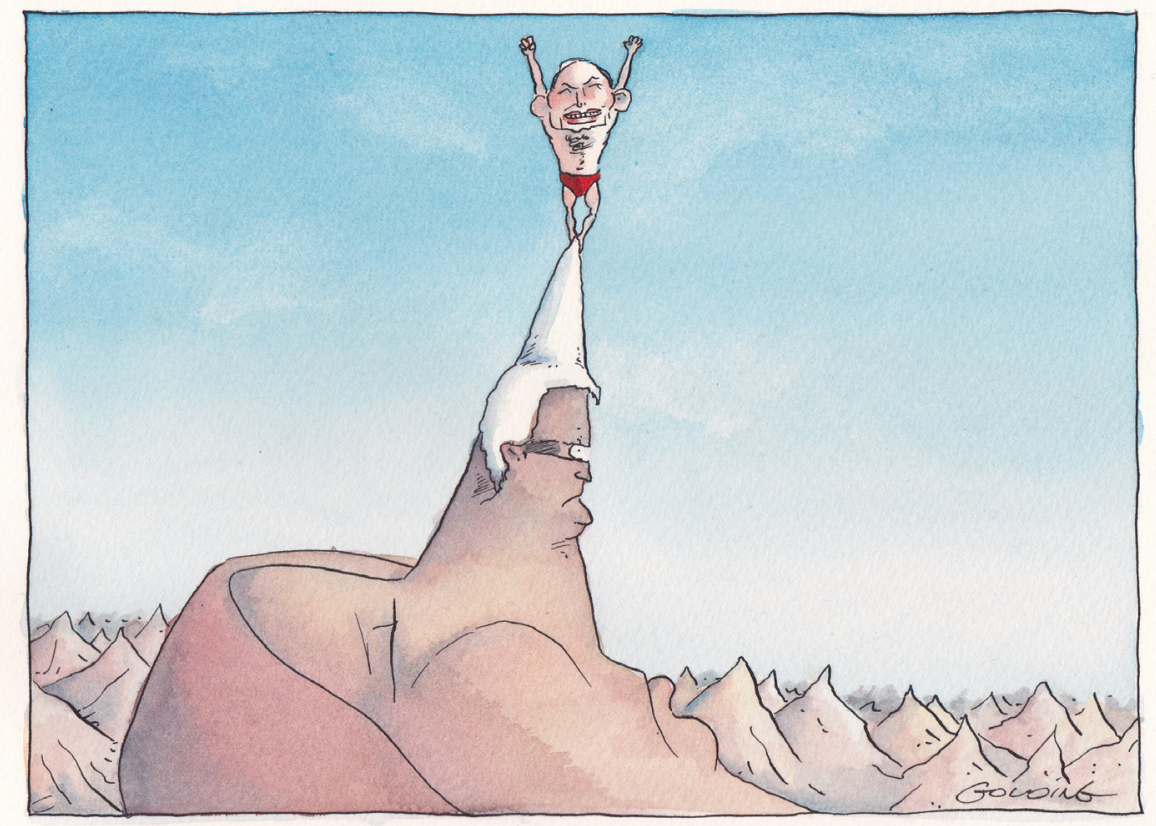

\section{Figure 28}

Source: Matt Golding, The Age, 8 September 2013.

Rudd's concerted effort to persuade voters that the Coalition had a secret agenda of 'cuts, cuts, cuts, cuts and more cuts' ultimately failed to resonate because, as Leak suggests, Abbott had already cut away his credibility. The irony is that over four years Abbott was arguably the most negative opposition leader in national political history. Yet when the election of 2013 finally arrived, the job of opposition was done and he was able to campaign on a more positive note by promising voters 'a grown-up government'. On the other hand, Rudd could only counter this picture with an overtly negative scare campaign; for frankly there 
really was relatively little good to say about the previous three years of Labor government and what positives there were, he was not responsible for! Here he is as Monty Python's Black Knight with 'just a scratch' - a fitting requiem for Kevin13.

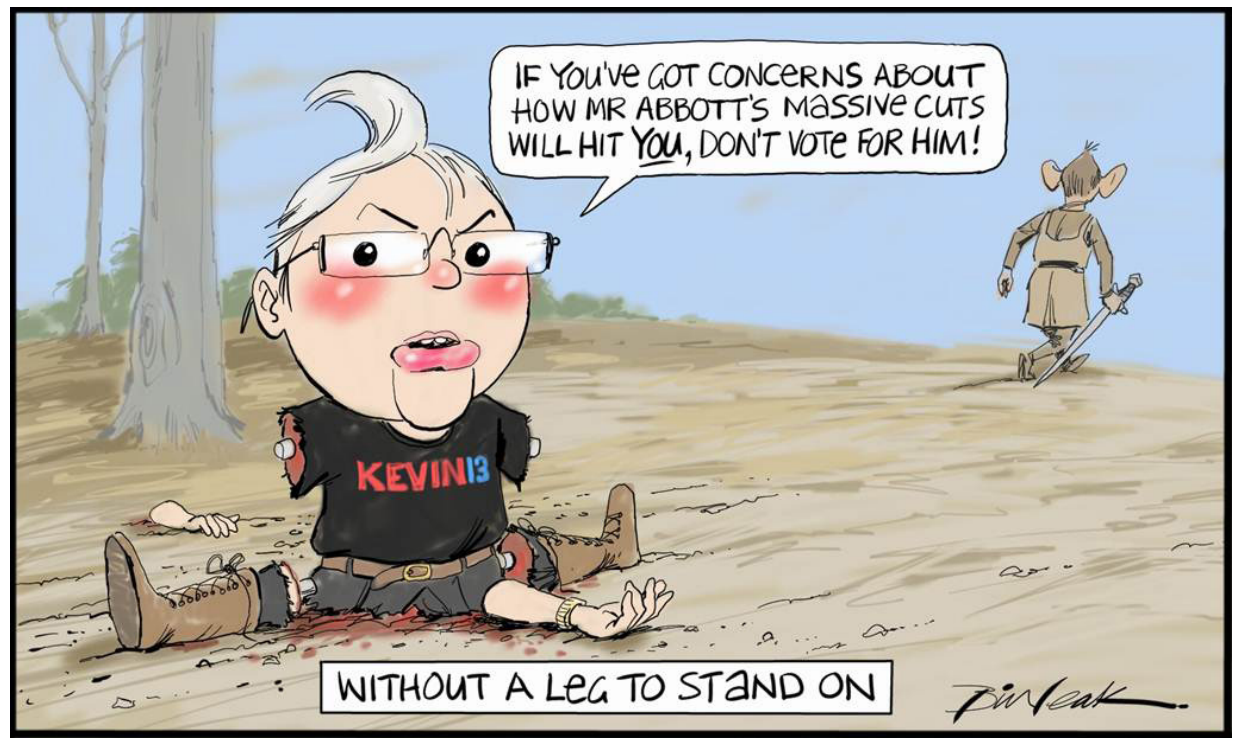

Figure 29

Source: Bill Leak, The Australian, 7 September 2013.

\section{References}

Bramston, Troy. 2013. 'Captain Chaos major pain for ground control'. The Australian, 9 September, viewed 9 September 2013:<www.theaustralian. com.au/national-affairs/election-2013/captain-chaos-major-pain-for-groundcontrol/story-fn9qr68y-1226714852806>.

Brent, Peter, 2013. 'Opposition leader Newspoll net satisfaction graphs'. The Australian, Mumble, 21 August, viewed 21 August 2013: <blogs. theaustralian.news.com.au/mumble/index.php/theaustralian/comments/ opposition_leader_newspoll_net_satisfaction_graphs/>.

Condren, Conal. 2012. 'Satire and definition'. Humor 25: 375-99.

El Refaie, Elisabeth. 2009. 'Multiliteracies: how readers interpret political cartoons'. Visual Communication 8(2): 181-205.

Gombrich, Ernst. 1978. Meditations on a Hobby Horse. Oxford: Phaidon Press. 
Greenberg, Josh. 2002. 'Framing and temporality in political cartoons: A critical analysis of visual news discourse'. Canadian Review of Sociology and Anthropology 39 (2): 181-98.

Hartcher, Peter. 2013. 'Collapse: how it all ended in tears'. Canberra Times. 20 November, viewed 26 November 2013: <www.canberratimes.com.au/ interactive $/ 2013 /$ meltdown/ $>$.

Hawker, Bruce. 2013. The Rudd Rebellion: The Campaign to Save Labor. Melbourne: Melbourne University Press.

Ireland, Judith and Jonathan Swan. 2013. 'Young, feisty and with sex appeal'. The Sydney Morning Herald, 13 August, viewed 13 August 2013: <www.smh. com.au/federal-politics/federal-election-2013/young-feisty-and-with-sexappeal-abbott-talks-up-candidate-20130813-2ru0b.html>.

Joye, Paula. 2013. 'Tony's Daughters are Dressing to Win'. The Sydney Morning Herald, 1 September, viewed 1 September 2013: <www.smh.com.au/lifestyle/ fashion/tonys-daughters-are-dressing-to-win-20130831-2sx0v.html $>$.

Kelly, Joe. 2013. 'Clive Palmer setting himself up for major fall'. The Australian, 12 August, viewed 12 August 2013: <www.theaustralian.com. au/national-affairs/clive-palmer-setting-himself-up-for-major-fall/storyfn59niix-1226695164061>.

Kerr, Joan. 1999. Artists and Cartoonists In Black and White. Sydney: Southwood Press.

Klausen, Jytte. 2009. The Cartoons That Shook the World. New Haven: Yale University Press.

Leys, Nick. 2013. 'Kevin Rudd-selfie-obsessed PM misses the mark'. The Australian, 10 August, viewed 10 August 2013:<www.theaustralian. com.au/media/kevin-rudd-selfie-obsessed-pm-misses-the-mark/storye6frg996-1226694575617>.

Manning, Haydon and Phiddian, Robert. 2002. 'Two men and some boats: the cartoonists in 2001'. In Marian Simms and John Warhurst (eds), The Centenary Election, St Lucia: University of Queensland Press.

Media Watch. 2013. 'The ad that didn't get up'. Television program, ABC Television, 9 September, viewed 13 January 2014: <www.abc.net.au/ mediawatch/transcripts/s3844762.htm $>$.

Phiddian, Robert. 2013. 'Satire and the limits of literary theories'. Critical Quarterly 55: 44-58. 
Press, Charles. 1981. The Political Cartoon. Rutherford: Fairleigh Dickinson University Press.

Scott, Steven. 2013. 'Katter Candidate Paul Hunter in revolt over preference deal with Labor in Forde'. Courier-Mail, 21 August, viewed 20 November 2013: <www.couriermail.com.au/news/queensland/katter-candidatepaul-hunter-in-revolt-over-preference-deal-with-labor-in-forde/storyfnihsrf2-1226700937030>.

Seymour-Ure, Colin. 1997. 'Drawn and quartered: how wide a world for the political cartoon?'. The Hocken Lecture 1996, The Hocken Library \& The New Zealand Cartoon Archive Trust. Dunedin: Printing Department, University of Otago.

Seymour-Ure, Colin. 2001. 'What Future for the British Political Cartoon?'. Journalism Studies 2(3): 333-55.

Seymour-Ure, Colin. 2003. Prime Ministers and the Media, Issues of Power and Control. Oxford: Blackwell.

Snow, Deborah. 2013. 'How Kevin Rudd's 2013 election campaign imploded'. The Sydney Morning Herald, 9 September, viewed 9 September 2013: <www. smh.com.au/federal-politics/federal-election-2013/how-kevin-rudds-2013election-campaign-imploded-20130908-2tebl.html>.

Williams, Pamela. 2013. 'How Kevin Rudd's campaign unravelled'. Australian Financial Review, 9 September, viewed 9 September 2013: <www.afr.com/p/national/how_kevin_rudd_campaign_unravelled_ MUATc7semL7gLrK69U2OvN>.

Wright, George. 2013. 'Address to the National Press Club'. Canberra, 29 October, viewed 15 January 2014: <d3n8a8pro7vhmx.cloudfront.net/ australianlaborparty/pages/1890/attachments/original/1383017072/George_ Wright_Address_to_NPC_Transcript.pdf $>$. 
This text taken from Abbott's Gambit: The 2013 Australian Federal Election, edited by Carol Johnson and John Wanna, published 2015 by ANU Press, The Australian National University, Canberra, Australia. 